\begin{tabular}{|c|c|c|c|l|l|l|}
\hline \multirow{2}{*}{ LASER } & WEA & WEA_2061 & \multirow{2}{*}{$\mathbf{Z}$} & Dispatch: 4/12/12 & Journal: WEA & CE: \\
\cline { 2 - 3 } \cline { 5 - 7 } & Journal Name & Manuscript No. & Author Received: & No. of pages: 10 & TS: Hema Priya \\
\hline
\end{tabular}

\title{
The English Channel 'tsunami' of 27 June 2011 - a probable meteorological source
}

\section{David $\equiv$ appin, ${ }^{1}$ Andrew Sibley, ${ }^{27}$ Kevin Horsburgh, ${ }^{3}$ Camille Daubord, ${ }^{4}$ Dave Cox ${ }^{5}$ and Dave Long ${ }^{6}$}

'British Geological Survey, Nottingham

${ }^{2}$ Met Office Hazard Centre, Exeter

${ }^{3}$ National Oceanography Centre,

Liverpool

${ }^{4} \mathrm{SHOM}$, Brest, France

${ }^{5}$ Flood Forecasting Centre, Exeter

${ }^{6}$ British Geological Survey, Edinburgh

On 27 June 2011 a tsunami struck the Yealm Estuary and anomalous tides were experienced from Portugal to the Straits of Dover. These events were caused by a meteotsunami driven by convective cells extending from the Bay of Biscay into the English Channel. This paper explains meteotsunamis, their causes, previous occurrences and, finally, what happened on this day.

The first national awareness that something strange had happened came two days later, on the 29th, when the press reported a tsunami striking southwest England between Penzance and Portsmouth (http:// www.guardian.co.uk/environment/2011/ jun/29/tsunami-cornish-shifting-waterlandslide). At St Michael's Mount (Cornwall) people on the causeway suddenly found themselves knee deep in water as the sea level rose rapidly and reported their 'hair standing on end' before the water rose. The tsunami flooded the Yealm at about 1030 BST as a bore flowing upriver (http://www. youtube.com/watch?v=hJSppdmO4Qc\&fea ture=related). At Marazion, the sea withdrew before the wave came in. Tidal anomalies of $20 \mathrm{~cm}$ were reported at Newlyn, around $30 \mathrm{~cm}$ at Plymouth and Weymouth, and $40 \mathrm{~cm}$ at Portsmouth. Approximately 200 miles of coastline were affected. No earthquakes were reported (R. Musson,

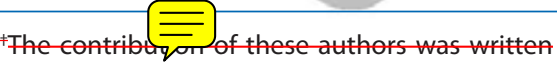
in the course of their employment at the Aet Office, UK, and is published with the permission of the Controller of HMSO and the Queen's Printer for Scotland.
British Geological Survey, pers. comm.), so as an alternative source a massive landslide located off the southwest of England on the continental slope was suggested. The tsunami, however, may not have been a geological event, but due to convective activity in the Bay of Biscay and English Channel. Meteotsunamis are common in other areas, such as the Mediterranean, and there have been previous unsubstantiated reports from Britain. Thus, for the first time, this event provided an opportunity to investigate a meteotsunami using an extensive data base of meteorological and tidal data.

\section{Tsunamis and meteotsunamis}

Tsunamis result predominantly from earthquakes, with subsidiary sources including subaerial and submarine landslides, volcanic collapse and $\bar{\equiv}$ tion, and, very rarely, bolide (meteoric fikeball) impact. They are shallow water waves, whose wavelengths are at least 20 times the water depth. Their speed is related to this depth and they travel at $s=\sqrt{ } g h$, where $g$ is the gravitational acceleration $\left(9.8 \mathrm{~ms}^{-2}\right)$ and $h$ is the water depth. Thus the deeper the water, the faster the waves travel. Meteotsunamis are also shallow water waves, but are created by air pressure disturbances moving over the sea (Monserrat et al., 2006). In the open ocean the disturbances generate surface shallow water waves that, near the coast, are amplified by resonance. At water depths of $4000 \mathrm{~m}$ a tsunami wave will travel at $200 \mathrm{~ms}^{-1}$. But in the deep ocean, weather-induced systems will travel at less than $50 \mathrm{~ms}^{-1}$ so are unable to keep pace with any shallow water waves that may be created by an air pressure disturbance. Notwithstanding, air pressure disturbances may still generate surface waves over the deep ocean but their height will remain very small because the pressure wave and induced surface wave in the ocean will be out of phase. They only come into phase when water depths decrease and the speed of the shallow water wave decreases. Thus meteotsunamis may be defined as small-amplitude, atmospherically-generated waves that amplify as they shoal and then resonate in bays and harbours. They can cause significant damage to coastal infrastructure and occasionally result in fatalities (e.g. Hibiya and Kajiura, 1982).

In contrast to impulse-type tsunamis, sourced almost instantaneously from an earthquake, the atmospheric disturbances that generate meteotsunamis as they interact with the ocean may last from minutes to hours, driving the tsunami forward in the process. In this respect, meteotsunamis are similar to submarine landslides. However, once created, tsunamis from all sources propagate in the water in the same way and have similar coastal dynamics. The tsunami wave may be amplified by:

resonance between the speed of the disturbance and shallow water wave speed,

2. wave energy flux conservation as the wave travels into shallow water or

3. resonance at the coast in a harbour, bay or inlet.

For an observer on the coast the tsunamis from the different sources would look the same: the difference is only in their source and their typical amplitudes.

The meteorological disturbances that source meteotsunamis may be atmospheric gravity waves, active frontal passages and downdraughts or squall lines from convective activity. Gravity waves, with periods of 10-50 minutes, are particularly linked to a resonant response in bays and inlets. Sharp pressure changes of $2-10 \mathrm{mbar}$ in a few minutes may occur along active frontal boundaries and near convective thundery cells; pressure rises (or falls) lead to a small depression (or elevation) of the sea surface, together with an increase in wind stress on the water surface (Nudelman et al., 2010).

The initial atmospheric pressure change only results in a corresponding sea-surface variation of a few centimetres: for example a $1 \mathrm{mbar}$ change in pressure would result in a sea-level perturbation of approximately $1 \mathrm{~cm}$ due to the so-called inverse barometer effect. Thus the mesoscale atmospheric phenomena described can only produce a significant sea-level response when resonance occurs between the ocean and the atmospheric disturbance, when there is significant amplification of the ocean surface 


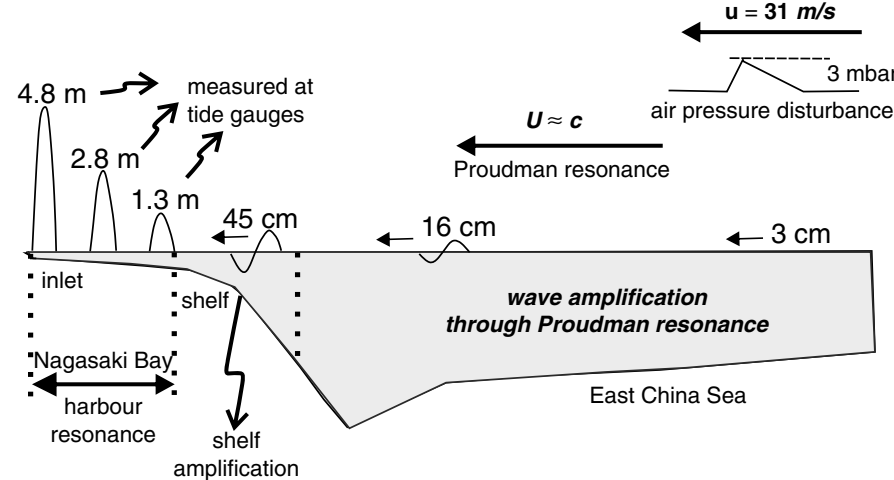

Figure 1. A sketch illustrating the physical mechanism responsible for formation of the catastrophic meteotsunami at Nagasaki Bay (Japan) on 31 March 1979. The initial pressure jump over the western part of the East China Sea was about 3mbar. The long waves generated by the event first amplified from $3 \mathrm{~cm}$ to $16 \mathrm{~cm}$ as a result of the Proudman resonant effect, then to $45 \mathrm{~cm}$ due to the shelf amplification and finally to $478 \mathrm{~cm}$ at the head of the bay due to the harbour resonance. (Modified from Monserrat et al., 2006.)

wave, or through the continuous input of energy. During resonance, the atmospheric disturbance propagating over the ocean surface is able to generate significant long ocean waves by the continuous pumping of energy into these waves (Monserrat et al., 2006). The most likely resonances are those of:

1. Proudman (1929), when the meteorological disturbance or front travels at about the same speed as the shallow water wave speed offshore;

2. Greenspan (Raichlen, 1966), when the alongshore component of the atmospheric disturbance velocity equals the phase speed of the $j$-th mode of edge waves; and

3. shelf resonance, Rabinovich (1993) when the atmospheric disturbance and associated atmospherically-generated ocean wave have periods and/or wavelength equal to the resonant period and or wavelength of the shelf region.

However, even a strong amplification in the ocean (through resonance or waveenergy flux conservation due to wave shoaling) is unlikely to create atmosphericallygenerated ocean waves large enough to extensively affect the open coast. For example, a 3-4mbar pressure jump and a 10-times resonant amplification will only produce $30-40 \mathrm{~cm}$ waves, so it is only when the waves enter a semi-closed coastal basin such as a bay, fjord or harbour, that they become high amplitude (Raichlen, 1966). These 'harbour oscillations' are due to the forcing of external long waves inside a basin with well-defined resonant properties and a large $Q$-factor (Quality factor: a measure of the damping in the system). The amplification depends on the frequency of the long waves $(f)$ and the resonant frequency of the basin $\left(f_{0}\right)$. Where the basin is elongate and narrow, the $Q$ factor is large and the amplification increased. Waves approaching
V-shaped harbours and bays are funnelled towards shore and energy density also increases (Figure 1). The relationship between the orientation of the arriving waves and the harbour/bay entrance is also important; with a greater resonance when the harbour or bay is facing the approaching waves.

The unlikely coincidence of the different causative factors may suggest that meteotsunamis are quite rare events. In addition, the similarity of their run-ups to tsunamis

\section{Where do we find meteotsunamis?}

from other sources may lead meteostsunamis to be catalogued as 'tsunami-like' events or events of 'unknown origin' (e.g. Dawson et al., 2000; Haslett and Bryant, 2009). Surprisingly, however, there are numerous descriptions of meteotsunamis from many parts of the world.

There are a number of locations where they are common; for example, in the Adriatic Sea, the western Mediterranean, Japan and the USA. In the Adriatic Sea in 1978 and 2003, meteotsunamis sourced from atmospheric gravity waves caused waves of 6-8m (Vilibic and Sepic, 2009). On Menorca, in June 2006, a convective, squallinduced pressure jump travelling at resonant speed created a major meteotsunami that hit Ciutadella Harbour (Jansa et al., 2007). Initially, water levels dropped by $4 \mathrm{~m}$, and when the water returned 40 boats were sunk or damaged. The origin of these events is reasonably well-known (Monserrat et al., 2006). In the western Mediterranean during the late spring and summer, gravity waves travelling from southwest to northeast across the ocean cause atmospheric pressure disturbances. Their velocities of $22-30 \mathrm{~ms}^{-1}$ are in resonance with the local water depths of less than $100 \mathrm{~m}$ (in which long-wave speed is $\sim 31 \mathrm{~ms}^{-1}$ ), suggesting a Proudman relationship. The 2006 pressure jump of $7 \mathrm{mbar}$ developed over 30 minutes with a 5 mbar in 5 minutes. In Japan, in 1979 a meteotsunami struck Nagasaki Bay (Hibiya and Kajiura, 1982). The source was a pressure jump of about $3 \mathrm{mbar}$ in the East China Sea. As the pressure front travelled the $300 \mathrm{~km}$ towards Nagasaki Bay, the $\sim 3 \mathrm{~cm}$

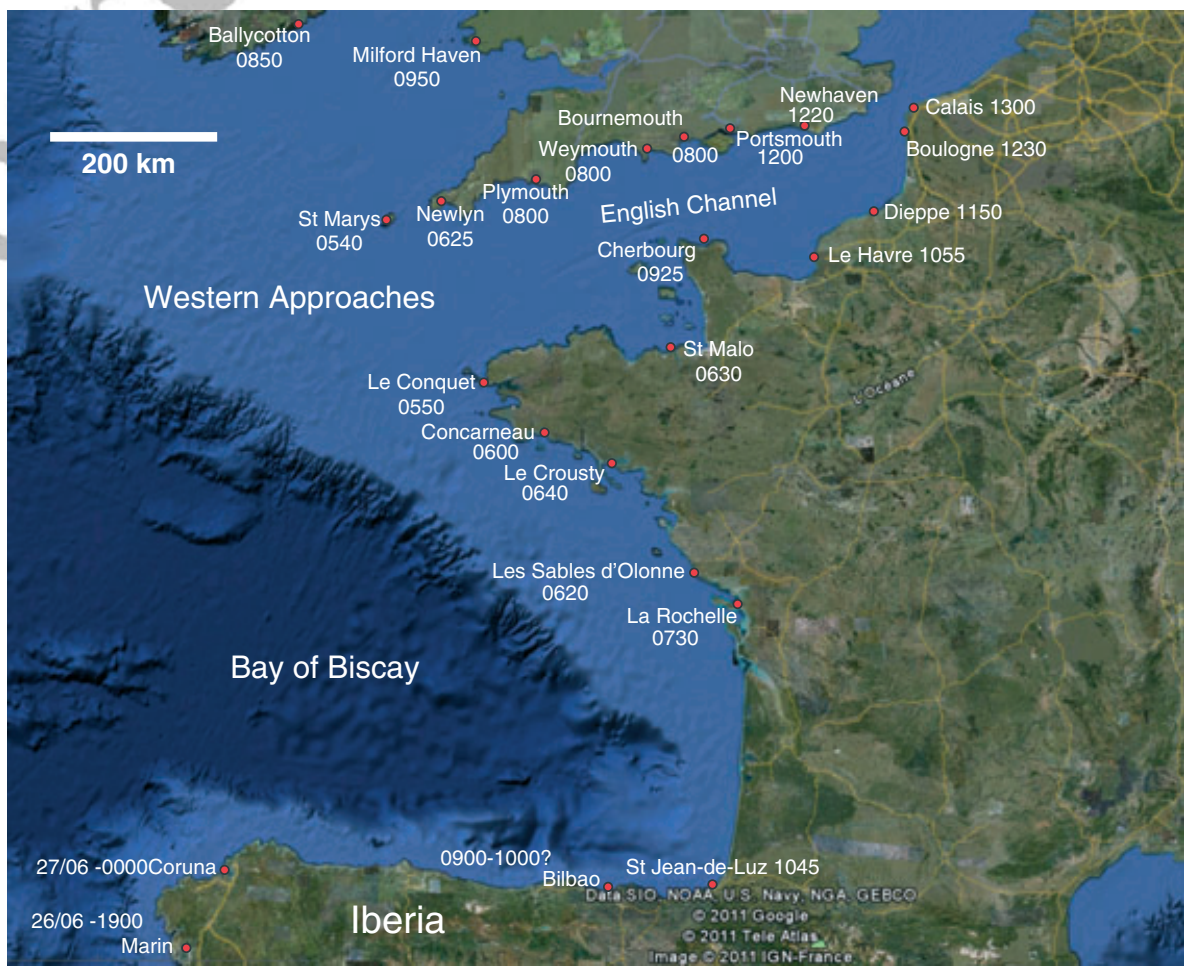

Figure 2. Locations of tide gauges with anomalous readings and their arrival times in UTC: all dates are 27 June 2011 except those in Spain which are from the 26th.
1 2 3 4 5 6 7 8 9 
waves created were amplified by Proudman resonance to about $12-14 \mathrm{~cm}$ (Figure 1). Over the shelf, as water depths shoaled, the wave height was again amplified to $45 \mathrm{~cm}$. Finally, at the head of the bay, wave heights of nearly $5 \mathrm{~m}$ were formed through harbour resonance. In the USA, on Daytona Beach (Florida) in July 1992, an unexpectedly large ocean wave, peaking at $3 \mathrm{~m}$, surged over the beach resulting in injuries to 75 people. There was no obvious source for the wave, except a southward-propagating squall line that was eventually proposed as the most likely cause (Churchill et al., 1995).

In southern Britain a number of tsunamilike events have been described (Dawson et al., 2000; Haslett and Bryant, 2009; Haslett et al., 2009). Their identification, however, is mainly based on what they might not have been (storms, distant earthquake tsunamis etc) rather than what they actually are. For example out of 19 tsunami-like events, Haslett and Bryant (2009) only chose three likely candidates; 1892 (Yealm and Fowey estuaries), 1929 (Folkestone to Brighton) and 1966 (Devon and Pembrokeshire). Newig and Kelletat (2011) report another event in 1858 that struck the North Sea. All possible identifications are tenuous, and without any recorded meteorological or tidal data to support them.

\section{The tsunami of 27 June 2011}

The event of 27 June 2011 is well documented. In addition to tide gauge (Figures 2-5) and meteorological data (Figures 6 and 7), there are personal accounts and a video (Figure 8). The strong association between the meteorological situation and the tide-gauge anomalies, together with the anecdotal evidence and the video from the Yealm Estuary, near Plymouth, all suggest the likely source is a meteotsunami. As a result, other 'geological' tsunami sources, such as earthquakes and submarine landslides, are considered unlikely.

\section{Meteorological situation}

Overnight 26-27 June slow-moving cold fronts lay from Scotland southwest to the west of Iberia and a developing area of thunderstorms over western Iberia moved quite quickly into the Bay of Biscay and then towards the north to northeast (Figures 6 and 7). The radio-sonde at La Coruna at 0000 UTC on 27 June, reported a wind velocity of $200^{\circ} 23 \mathrm{~ms}^{-1}$ at $573 \mathrm{mbar}$ (Figure 9(a)), giving an indication of the speed of movement of the thundery cells. The vertical profile highlights air with lower wet bulb potential temperature $\left(\theta_{w}\right)$ overlying air with higher $\theta_{w}$; the air mass was therefore potentially unstable to strong convection with the potential for strong
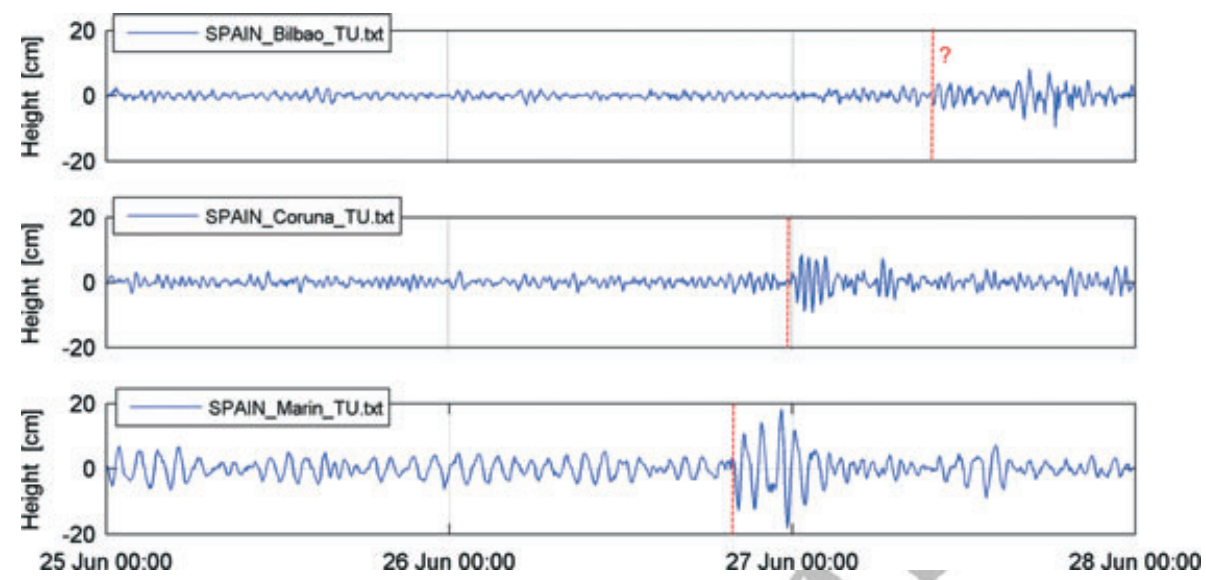

Figure 3. High-resolution tide gauge data from Spain between 0000 UTC on 25 June 2011 and 0000 UTC on 28 June 2011. Red vertical lines indicate the start of the anomalous tide gauge readings; note that the anomalous signal at Coruna may be earlier at 1900 UTC. (See Figure 2 for location and text for discussion.)
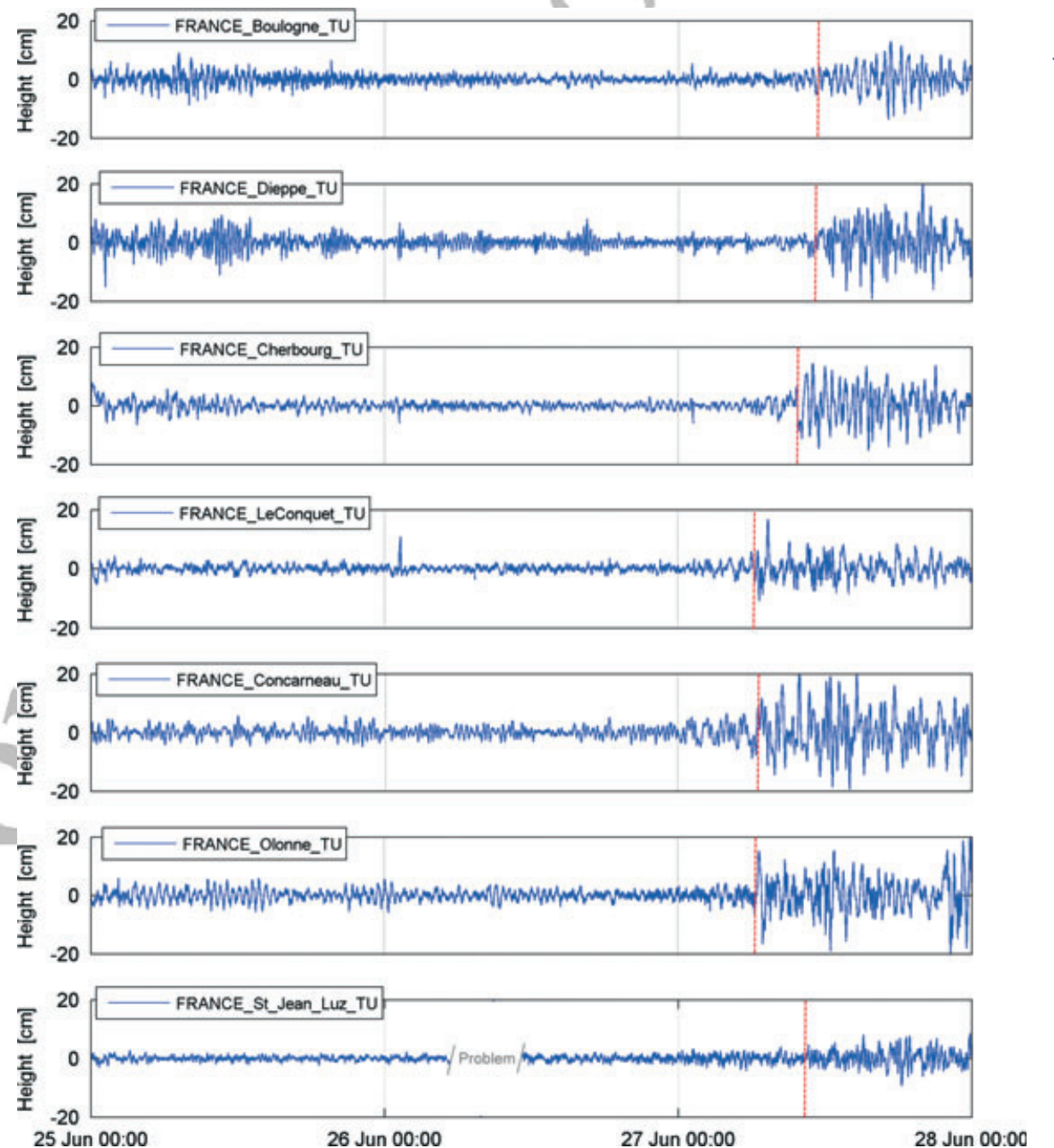

Figure 4. High-resolution tide gauge data from locations along the French coast between 0000 UTC on 25 June 2011 and 0000 UTC on 28 June 2011. Data above Le Conquet is from gauges along the English Channel (La Manche), data below is from gauges from the west coast of France. Red vertical lines indicate the start of the anomalous tide gauge reading. (See Figure 2 for location of stations and text for discussion.)

downdraughts and squall lines, particularly on the forward flank of these quite fastmoving, medium-level cells. Estimations from the La Coruna profile suggest a negative Convectively Available Potential Energy
(CAPE) value of approximately $850 \mathrm{Jkg}^{-1}$, which may yield an average downdraught speed of around $20 \mathrm{~ms}^{-1}$ in the right circumstances (by converting potential energy into kinetic energy) although, due to 

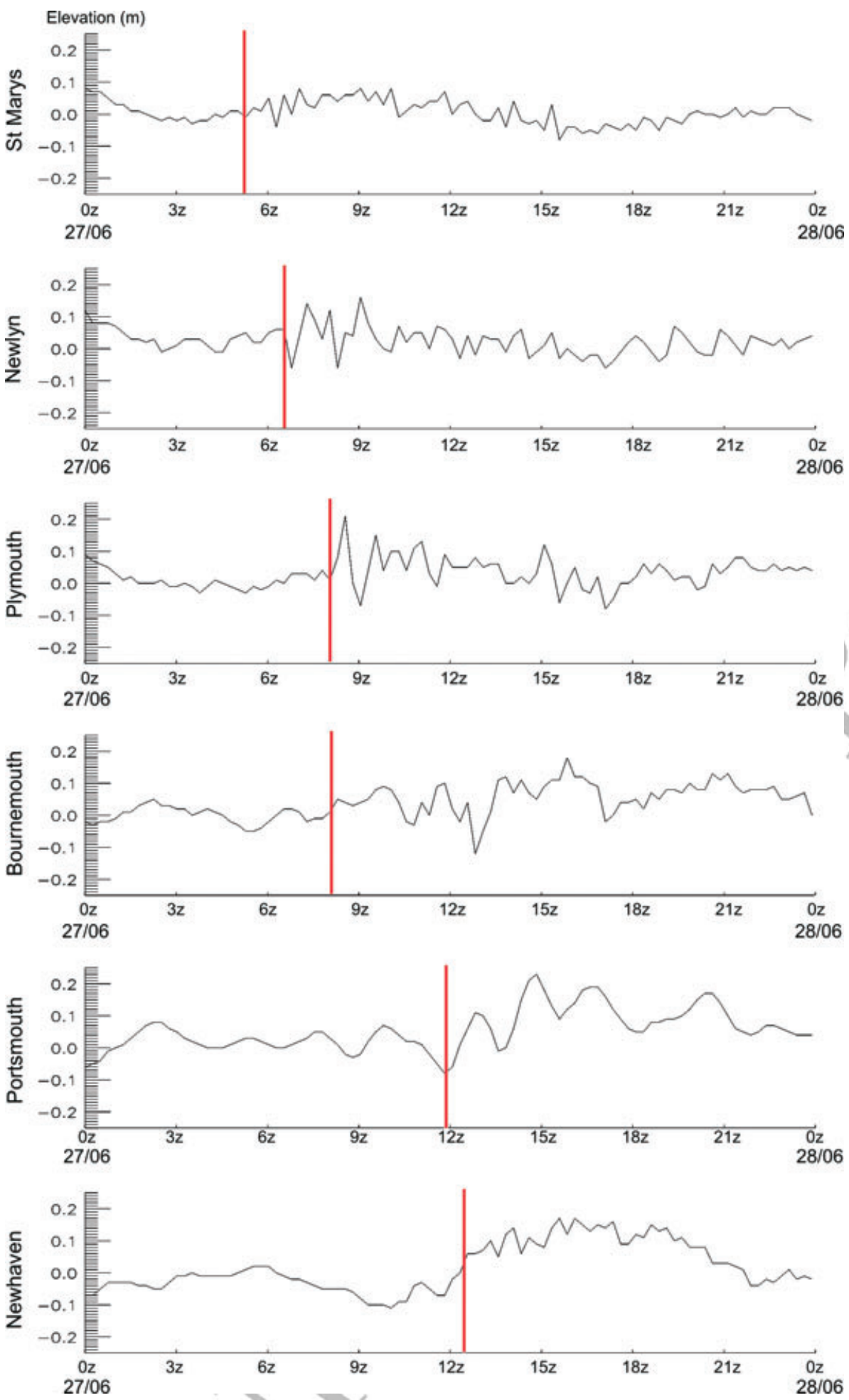

Figure 5. 15-minute tide data from gauges in southern England. (See Figure 2 for location and text for discussion). Times in UTC. energy loss through other processes such as friction and mixing, the speed may have been somewhat less. Once formed, the downdraught would move out horizontally with gust speeds of some $20 \mathrm{~ms}^{-1}$ that would decrease away from the source. The area producing the downdraughts would also be moving to the north or northeast at $23-25 \mathrm{~ms}^{-1}$.

During the morning of 27 June, oneminute surface pressure data from the buoys offshore of Brittany show a sharp fall

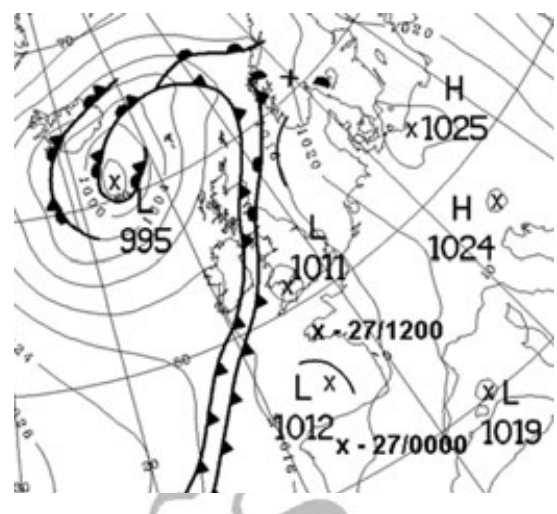

Figure 6. The synoptic situation over the northeast Atlantic at 0600 UTC on 27 June 2011. The position of the Biscay low is also shown for 0000 and 1200 UTc. (ङ) Crown Copyright, Met Office.)

(a)

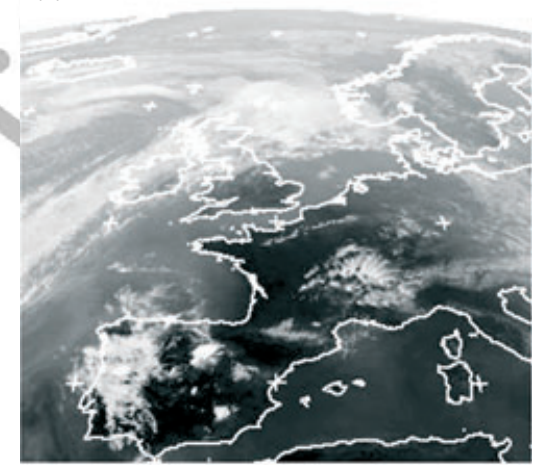

(b)

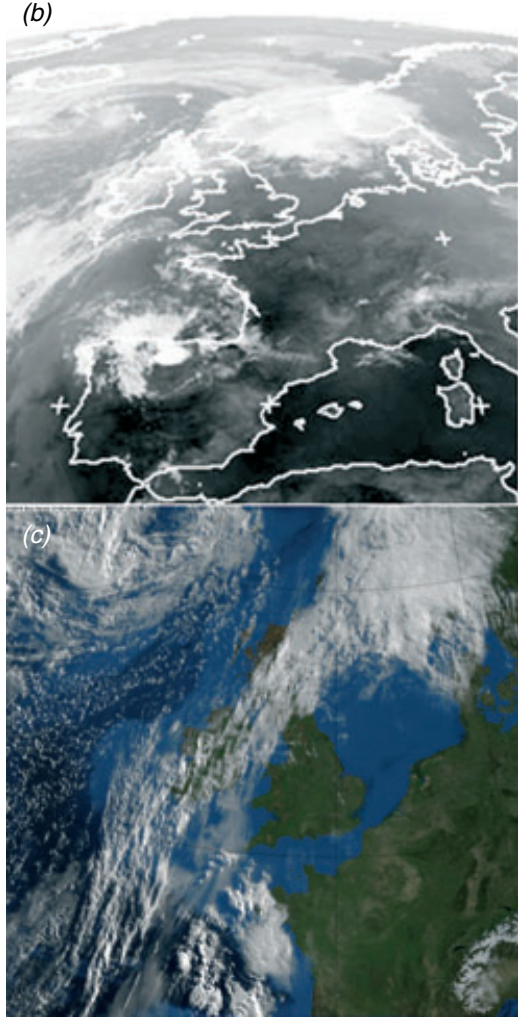

Figure 7. Infrared satellite imagery over Britain and northern Europe for (a) 1800 UTC on 26 June, (b) 0000 UTC on 27 June and (c) 0600 UTC on 27 June 2011. (a) and (b) are NEODASS satellite imagery (IR images from EUMETSAT) provided by NERC Satellite Receiving Station, Dundee University, (c) is (c) Crown Copyright, Met Office.) in pressure between 0500 and 0800 UTC, and this transferred over the following one to two hours to stations in the southwest UK (Figure 10). The buoys off Brittany record (Figure 10): the earliest of these falls of 2-3mbar is between 0530 and 0600 UTC at Pointe du Raz and Penmarche, followed by a 4mbar fall between 0627 and 0653 UTC at Ouessant and a $5 \mathrm{mbar}$ fall between 0720 and 0811 UTC at Belle-lle. One-minute air pressure data at stations in southwest

\section{1 \\ 3
4 \\ 5 \\ 6 \\ 9}

2

10

11

12
13

14

15

16

17

18

19

20

21

22

23

24

25

26

27

28

29

30

31

32

33

34

35

36

37

38

39

40

41

42

43

44

45

46

47

48

49

50

51

52

53

54

55

56

57

58

59

60

61

62

63

64

65

66

67 


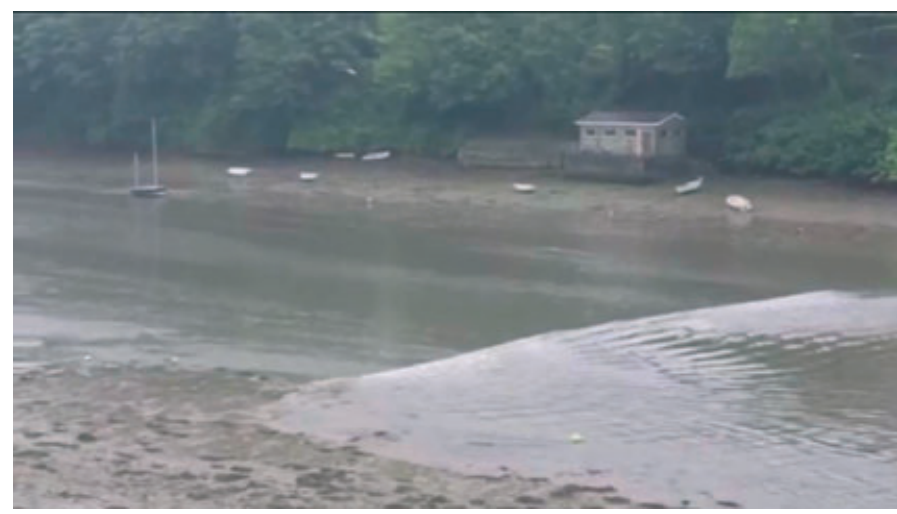

Figure 8. Screen shot from the video of the Yealm tsunami taken at 0930 UTC on 27 June 2011 (by permission of Simon Fitch.)

(a)
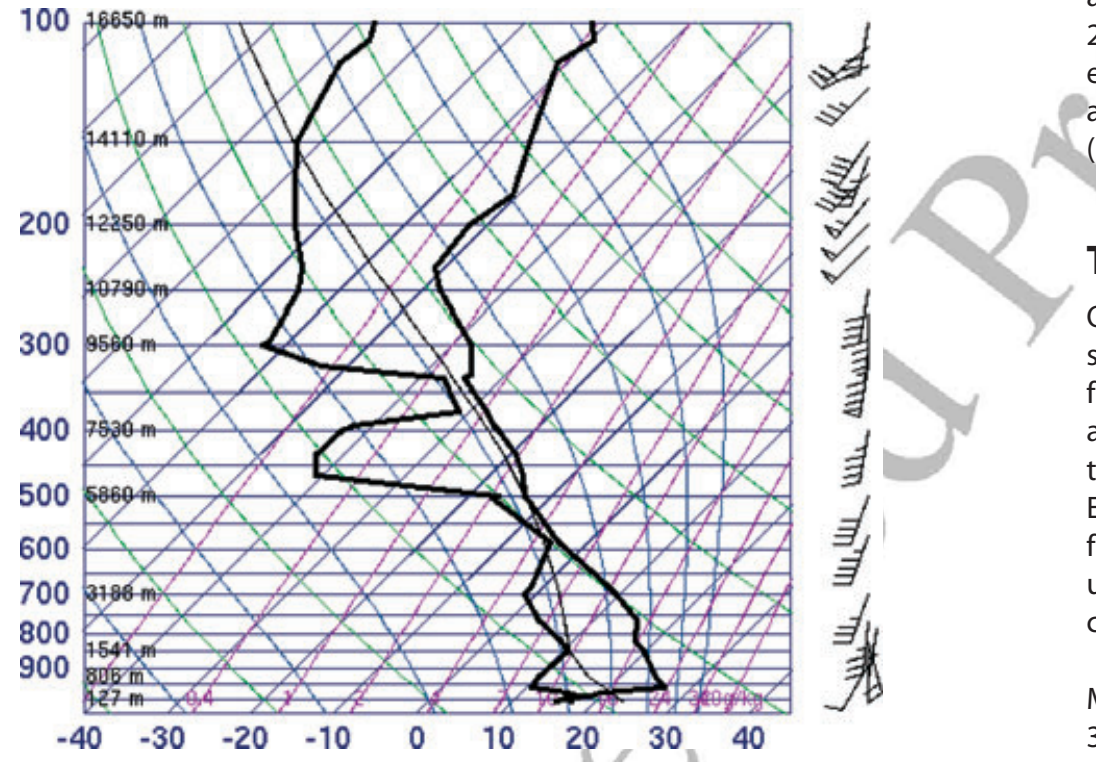

Figure 9. Vertical profiles for (a) La Coruna at 0000 UTC on 27 June 2011 and (b) for Palma de Mallorca at 1200 uTc on 15 June 2006.

Britain show pressure falls of between 1 and $2 \mathrm{mbar}$ : the first fall, of just over $2 \mathrm{mbar}$, is between 0614 and 0624 UTC at St Marys, followed by $1.5 \mathrm{mbar}$ between 0640 and 0711 UTC at Camborne and 1 mbar between 0642 and 0710 UTC at Culdrose. There is another fall of $1.5 \mathrm{mbar}$ at Culdrose a just after 1000 UTC but no rapid fall in pressure at Plymouth until 1100 UTC. At the buoy located at $49.0^{\circ} \mathrm{N}$ and $2.9^{\circ} \mathrm{W}$ (Figure 10) the hourly data shows a fall of $2 \mathrm{mbar}$ between 0900 and 1000 UTC.
The Met Office's internal Model Assessment and Emphasis, issued at 0910 UTC on 27 June, mentioned the risk of potentially damaging downdraughts, termed 'm $\equiv$ pursts', and possible gusts of up to 2 . Th5 . This warning was based on the UK Met Office UKV $1.5 \mathrm{~km}$ model (model run time 0000 UTC on 27 June 2011) that predicted a strong gust front at $10 \mathrm{~m}$ in the English Channel at 0900 UTC and 1000 UTC in association with the convective cells (Figure 11). The aforementioned buoy recorded a gust of $15 \mathrm{~ms}^{-1}$ in the hour to 0900 UTC, and another to $16 \mathrm{~ms}^{-1}$ up to 1100 UTC which coincided with marked surface pressure changes of around $2 \mathrm{mbar}$. The 1200 UTC radio-sonde at Camborne showed a $700 \mathrm{mbar}$ wind of $215^{\circ} 22 \mathrm{~ms}^{-1}$, and at Brest the $700 \mathrm{mbar}$ wind is $195^{\circ}$ 20 $\mathrm{ms}^{-1}$ (http://weather.uwyo.edu/upperair/ europe.html), largely confirming what was already noted from the La Coruna ascent (Figure 9).

\section{Tide gauge data}

On the 26 and 27 June, anomalous tides and seiches were recorded at many tide gauges from as far afield as Britain, Ireland, France and Spain (Figures 2-5). All high-resolution tide data shown here, except that from England (because it is 15-minute data), is filtered to plot high frequency variations using a Butterworth filter with a $1 / 9000 \mathrm{mHz}$ cut-off applied.

The first anomalous tidal reading is at Marin at 1900 UTC on 26 June (Figures 2 and 3), with others following at La Coruna (0000 UTC on 27 June), although this may have happened earlier (at 1900 UTC) and Bilbao (about 0900-1000 UTc). In France the first anomalous reading was at Le Conquet in Brittany at 0550 UTC on 27 June and then successively southward along the Atlantic coast of France arriving at the southeast corner of the Bay of Biscay at St Jean-de-Luiz at 1045 UTC (Figures 2 and 4). On the French coast of the English Channel, after Le Conquet, the anomalous readings are recorded at successive gauges before reaching Calais at 1300 UTC. On British tide gauges (Figures 2 and 5), because the data is recorded at 15 -minute intervals, the start times of the anomalous readings cannot be as accurately identified, but the first recording is identified at St Mary's (Isles of Scilly) at about 0540 UTC, and then eastward along the south coast, reaching Newhaven at about 1220 UTC. It was not recorded at Dover. The signal at most gauges is very clear, except at stations in mid-Channel. The maximum wave height is $20 \mathrm{~cm}$ at Concarneau, but generally the signal is small $(10 \mathrm{~cm})$. There is no diminution in amplitude in a west-east or north-south direction, although the signal seems to be higher amplitude along the French coast, 

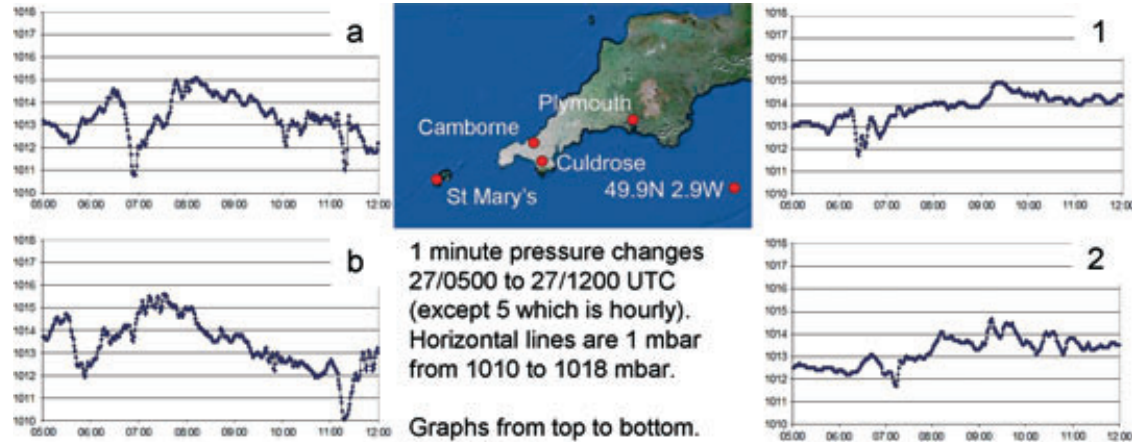

1 minute pressure changes $27 / 0500$ to $27 / 1200$ UTC (except 5 which is hourly). Horizontal lines are $1 \mathrm{mbar}$ from 1010 to $1018 \mathrm{mbar}$.

Graphs from top to bottom.

(1) St Mary's

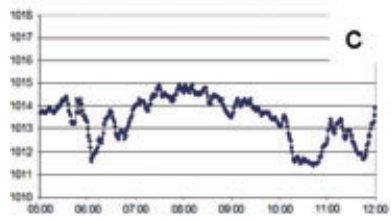

(2) Camborne

(3) Culdrose

(4) Plymouth

(5) Buoy $49.9 \mathrm{~N} 2.9 \mathrm{~W}$

(a) Ouessant

(b) Pointe du Raz

(c) Penmarche

(d) Belle-lle

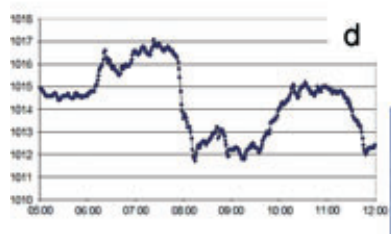

(e) lle d-Yeu
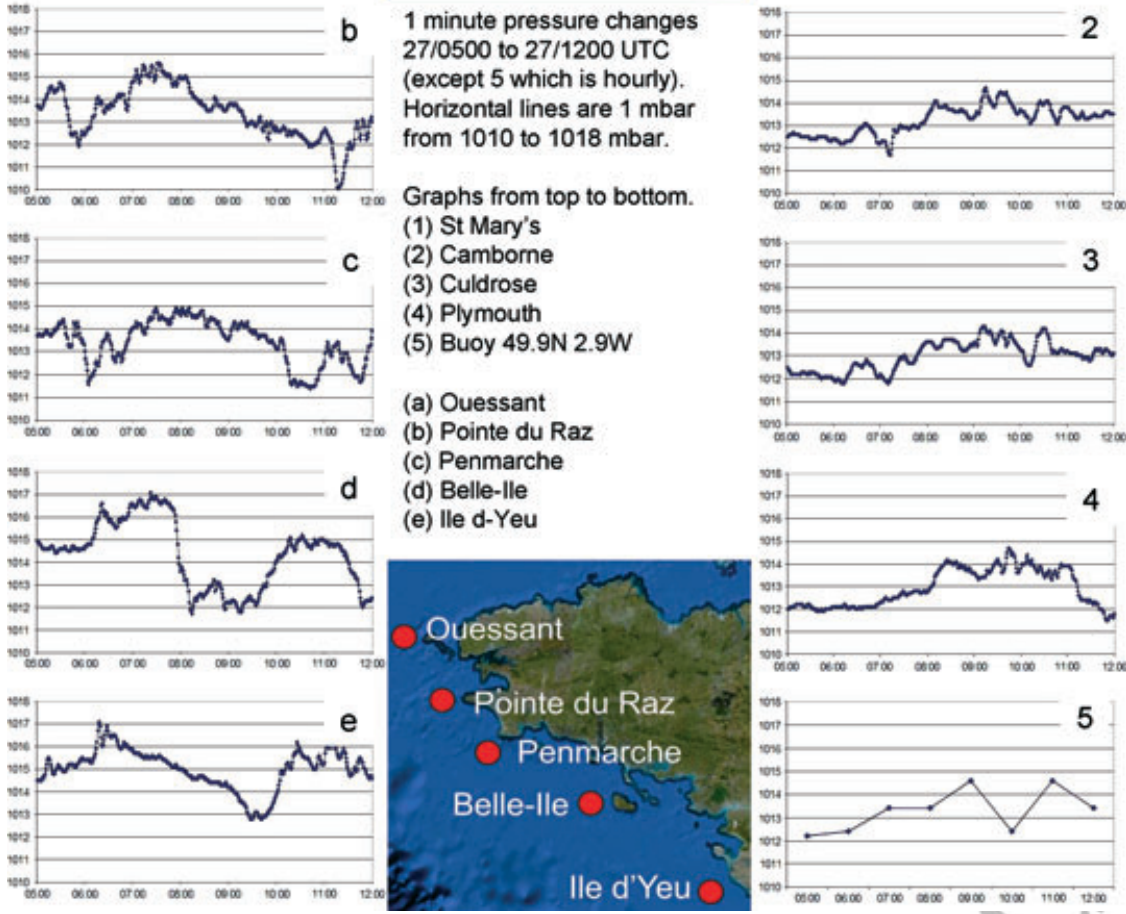

Figure 10. One-minute pressure changes between 0500 and 1200 uTC on 27 June 2011 at (a-e). Buoys off Brittany (data courtesy of Denis Paradis, Meteo France) and (1-4) locations in southwest England (5) shows 15 minute data from an offshore buoy at $49.0^{\circ} \mathrm{N}$ and $2.9^{\circ} \mathrm{W}$ for the same period. (Insets show locations.)
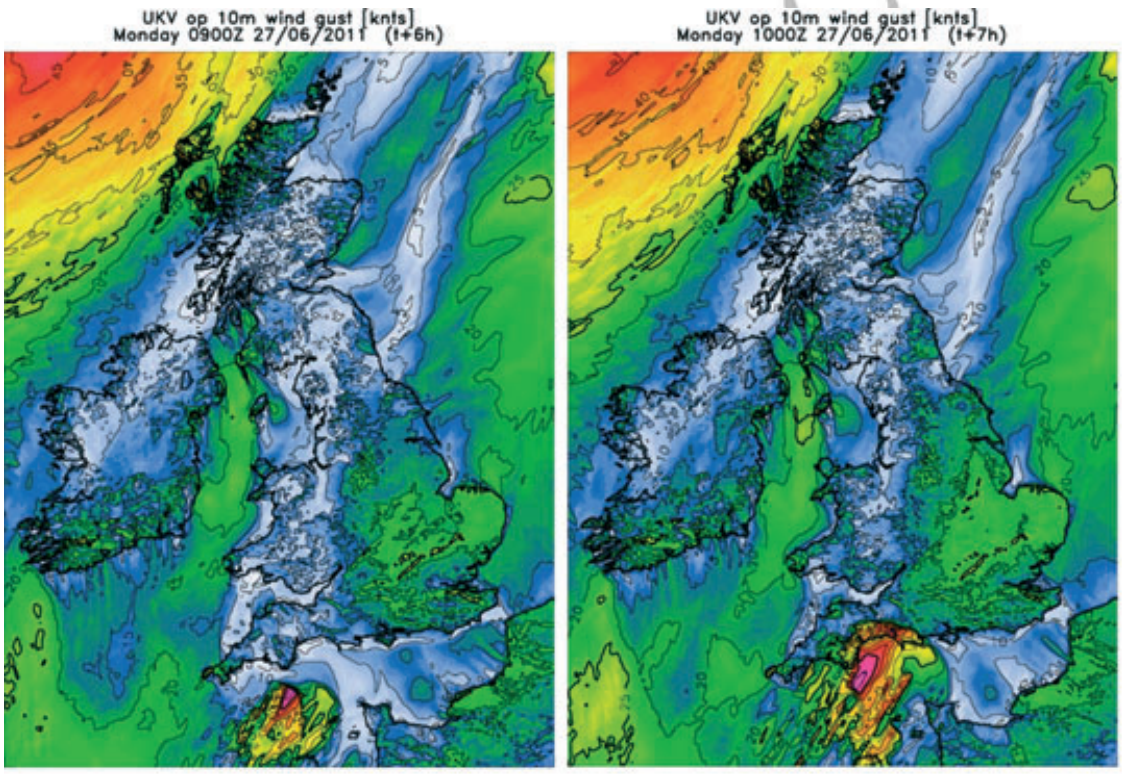

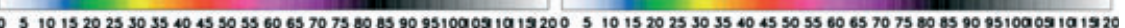

Figure 11. UK Meteorological Office forecasting model UKV (1.5km grid length) run at 27 June 2011 0000 UTC for 0900 UTC and 1000 UTC. Scale: wind gusts in knots. (๑ Crown Copyright, Met Office.)

consistent with a Coriolis effect on the long wave. There is strong seiching, especially at British tidal stations in mid-Channel (Weymouth and Bournemouth) that lasts up to 24 hours.

The absence of an associated earthquake, together with the regional extent of the tide gauge anomalies, in the context of the associated convective weather systems, immediately suggested a meteotsunami as the source of the oceanic events on 27 June 2011. With regard to submarine landslides, these are not instantaneously triggered, with the most commonly cited cause of failure an earthquake; so these too as a source were also discounted.

Turning to other sources of the tidal anomalies, the most striking correlation was between their (generally) northeastward progression, first identified in Spain and lastly in the Dover Strait, with the passage of storm cells from Portugal/Spain into the Bay of Biscay and then into the English Channel. However, detailed comparison of the tidal and meteorological data sets indicates that the correlation is not straightforward. Initially, without the tide data from Spain, it seemed that the thundery cells located off Brittany (Figure $7(\mathrm{c})$ ) were the source of the tidal anomalies that progressed southward and eastward from Le Conquet, and this indicated a strong correlation (cf. Figures 2 and 7). However, when the Spanish tide data became available, they showed anomalies nearly 11 hours earlier than the first off Brittany, so an additional source was required. The most obvious alternative was the cold front off western Europe, extending from west of Iberia to Britain (Figures 6 and 7). However, the front was not active enough to sufficiently affect the sea surface. The pressure gradient across the front is weak, and the satellite imagery (Figure 7) showed only layer cloud. In addition, the vertical sounding from Valentia (southern Ireland) at 0000 UTC on 27 June 2011 (not shown) shows a stable profile, so downdraughts would not be expected.

Referring to an earlier satellite image from 1800 uTc on 26 June (Figure 7(a)), we discovered that the convective weather system in the Bay of Biscay originated earlier off Portugal, thereby providing a possible source for the tidal anomalies at Marin and La Coruna. Support for this interpretation was from the radio-sonde at La Coruna at 0000 UTC (Figure 9) that showed a potentially unstable air mass capable of causing strong downward wind gusts. In this model, the evidence for the unstable vertical weather profile from La Coruna supports the formation of downdraughts that may then have generated the long-period wave through the effect of localised pressure differences and wind stress on the sea surface. It is likely that there were several downdraughts at different times, emanating from the convective cells lying near Coruna and subsequently moving towards the north or northeast.

However, this source off Portugal could not explain the timing of the tidal anomalies recorded along the north coast of Spain and
2 3 5 6 7 8 
Table 1

Calculations of shallow water wave speed between locations in England, France and Spain.

\begin{tabular}{|c|c|c|c|c|c|c|}
\hline 1 From -to & $\begin{array}{l}2 \text { Time of tidal } \\
\text { anomaly (UTC) }\end{array}$ & $\begin{array}{l}3 \text { Distance } \\
\text { (metres) }\end{array}$ & 4 Time (sec) & $\begin{array}{c}5 \text { Wave speed } \\
\text { ( } \mathrm{m} / \mathrm{sec})\end{array}$ & 6 Water depth & $\begin{array}{c}7 \text { Wave speed } \\
(\mathrm{m} / \mathrm{sec})\end{array}$ \\
\hline Coruna-Bilbao & 27 July - 1045 & 50000 & 32400 & 1.54 & 100 & 31.30 \\
\hline Le Conquet-Calais & 27 July - 1300 & 500000 & 21600 & 23.15 & 50 & 22.14 \\
\hline Le Conquet-St J de L & 27 July - 1045 & 500000 & 18000 & 27.78 & 100 & 31.30 \\
\hline Le Conquet-Ballycotton & 27 July - 0850 & 400000 & 10800 & 37.04 & 100 & 31.30 \\
\hline Le Conquet-Bilbao & 27 July - 1045 & 570000 & 18000 & 31.67 & 100 & 31.30 \\
\hline Le Conquet to St Michael's Mount & 27 July - ?0800 & 160000 & 7200 & 22.22 & & 31.30 \\
\hline Le Conquet to Yealm & 27 July - 0930 & 200000 & $\sqrt[1]{\equiv}$ & 15.87 & 100 & 31.30 \\
\hline
\end{tabular}

Column 1 - Source and arrival locations. Column 2 - Wave arrival times from sourcee Column 3 - Distance between source and arrival locations. Column 4 - Time of wave travel between source and arrival locations, Column 1. Column 5 - Wave speed between locations in Column 1. Column 6 - water depth (m). Column 7 - Wave speed in water depths in Column 6.

their convergence with those believed to be from Le Conquet, at St Jean-de-Luz (Figure 2): the former would have had to travel about $500 \mathrm{~km}$ at $\sim 1.5 \mathrm{~ms}^{-1}$, an unlikely wave speed even in the shallowest shelf w $=$ lepths off northern Spain (Table 1), let $\overline{\bar{n}}$ in $\mathrm{e}$ in the deeper waters off the shelf. Working, therefore, on the basis of two source areas, the most likely additional meteorological one to that off Portugal was the very active convective cells located near Brittany at 0600 UTC on the 27 June (Figure 7(c)), which we had previously interpreted as the source of tidal anomalies along the west coast of France and the coastlines of the English Channel. Support for this interpretation was found in the air pressure data from the one-minute data recorded at the buoys off Brittany (Figure 10), which as previously described shows a series of high-frequency pressure variations of up to $5 \mathrm{mbar}$ : the earliest of these between 0530 and 0600 UTC at Pointe du Raz and Penmarche correlates with the first French tidal anomaly recorded at Le Conquet at 0550 UTC. We interpret the number of pressure falls recorded at the Brittany buoys as the result of a series of updraughts that probably initiated the meteotsunami at this location. The rapid 3 mbar fall at Ouessant in about 30 minutes (and the $5 \mathrm{mbar}$ fall at Belle lle in about 40 minutes) would be expected to raise the sea surface following an initial compression due to the downdraughts. Calculating the timing of wave arrival at the tide gauges in the southern Bay of Biscay from a source off of Brittany agrees roughly with the records (Table 1).

With regard to the pressure data in the English Channel, the most notable correlation is between the timing of the fall at 0540 UTC at St Mary's (Figure 10) with the falls recorded at the buoys off Brittany. The thundery cell off Brittany at this time (Figure 7(c)) extended northward over the Isles of Scilly, so we interpret a similar source to both pressure falls. The earlier arrival of the tidal anomaly at St Mary's, compared to Le Conquet, is probably an artefact of the low (15-minute) resolution of the data. Calculating the timing of wave arrival at the tide gauges in the eastern English Channel from a source off Brittany again agrees roughly with the records (Table 1 ).

The tide gauge anomalies provide an important context for the events on 27 June that received the most press attention, the Yealm tsunami and the anecdotes from St Mount's Bay. On the Yealm, the tsunami was reported as striking at 1030 BST (0930 UTC). If this was the case, then a wave from a source off of Brittany, travelling in water depths of about $100 \mathrm{~m}$, would have taken just under two hours to arrive at the Yealm (Table 1). Even allowing for the passage of the wave up-river (about $4 \mathrm{~km}$ ), this timing does not correlate with the source time of around 0600 UTC we propose for the tidal anomalies. Viewing the video on YouTube, together with others kindly provided by Simon Fitch who recorded it, it is apparent that there are a sequence of 'takes' over several hours (confirmed by discussion with Simon) as at the beginning the tide is low and at the end it is high. However, even if the reported timing is incorrect and the tsunami struck at low tide around 0815 UTC, then this still does not correlate with the proposed 0600 UTC source time.

Therefore, in the context of our conclusions from the tidal anomalies, it appears there were several sources for these, as well as for the Yealm tsunami which we consider to have originated from another convective cell in the English Channel. Referring to the radar imagery between 0830 and 0930 UTC we find support for this interpretation in that another cell was present between Brittany and the southwest and moving northeastwards (Figure 12). In addition, the data recorded at the buoy at $49.0^{\circ} \mathrm{N}$ and $2.9^{\circ} \mathrm{W}$ shows a fall in pressure between 0900 and 1000 UTC of $2.1 \mathrm{mbar}$ (Figure 10). We suggest that a downdraught ahead of this cell caused the Yealm tsunami. The weather
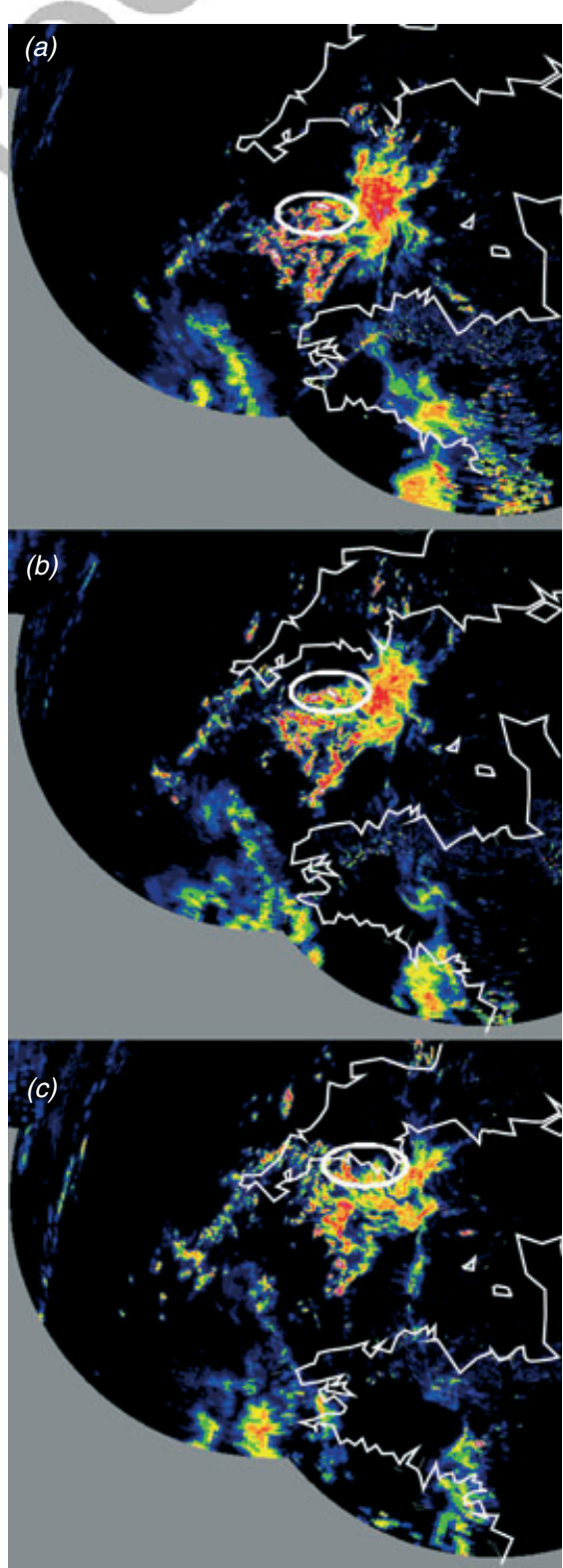

Figure 12. Radar frames between Brittany and Lyme Bay for (a) 0830 UTC, (b) 0900 UTC and (c) 0930 UTC on 27 June 2011, showing northeasterly moving medium-level storm cells. The white ellipse is the leading edge of the cell we consider the likely source of the Yealm tsunami. (๔ Crown Copyright, Met Office.) 
during videoing was overcast and wet, consistent with this scenario.

With regard to the rise in water at the causeway at St Michael's Mount, and the retreat of the sea at nearby Marazion, as we have no record of the timing we can only suggest a similar origin to the other anomalies recorded. If the source was off Brittany then the timing of wave travel would suggest these events occurred at about 0800 UTC; the thundery cells we cite as the source of the Yealm tsunami (Figure 12) would have been located overhead at this time and may have created the static that o would explain the reports of people's hair standing on end.

Based on the foregoing we attribute the anomalous tidal readings recorded on 27 June to meteorological effects, but are uncertain as to whether these can be classed as a meteotsunami, so we term them tidal anomalies (Monserrat et al., 2006). During 26-27 June the increase in pressure ahead of the thunderstorms resulted in a depression of the sea surface by several centimetres. As the storms moved away, a compensating fall in pressure would have raised the sea surface. If the main source of the tidal anomalies in the Channel and western France was off Brittany, then at these water depths (50-100m) Proudman resonance would be effectiv $\overline{\overline{\bar{\nu}}}$ ing a shallow water wave speed of $30-40 \mathrm{~ms}^{-1}$, which compares well with a cell speed of $20-30 \mathrm{~ms}^{-1}$ at these depths (Table 1). Proudman resonance therefore may be invoked for the anomalies. However, as most tide gauges are located in enclosed basins, there were certainly local amplifications due to seiching as well.

For the Yealm tsunami the pressure changes recorded at the land stations are not rapid enough to produce the size of wave reported (Figure 10). However, the newspaper claim of $0.8 \mathrm{~m}$ for this wave may be overstated, as an estimate from the video appears to be much lower, certainly less than $0.5 \mathrm{~m}$. Notwithstanding, we know from wave theory, and previous events in Japan and the Mediterranean, that as the wave propagated into shallow water it may have undergone modification and amplification through resonance, as noted above. If Proudman resonance is invoked, and the speed of the pressure anomaly is $25 \mathrm{~ms}^{-1}$ (the speed of the medium level convective cell that generated the downdraught), then the waves will come into phase when the water depth is $62.5 \mathrm{~m}$ : this is close to the depth of the English Channel between Brittany and the Yealm. Supporting evidence for the speed of the pressure anomaly comes from radar frames from between 0830 and 0930 UTC (Figure 12) that show the leading edge of medium-level storm cells moving northeast at $25-27 \mathrm{~ms}^{-1}$, from near Brittany to Lyme Bay. Other cells are then seen developing behind the leading edge in the English Channel as part of a complex system.

Overall, the evidence suggests that the Yealm tsunami and tidal anomalies are the result of Proudman resonance because we have positively identified an atmospheric source on the continental shelf. However, if they are a result of a downdraught that occurred over the deep ocean beyond the continental shelf, such as the trough west of Britain, then increase in the height of the initial wave might be due to wave energy flux conservation, as with tsunami waves from other geological sources. At ocean depths of $4000 \mathrm{~m}$, the long period wave is treated as 'shallow-water' and the wave speed is $\sqrt{ } g h$. From this, we deduce that when the wave travels into shallow water, a $4 \mathrm{~cm}$ wave generated by a $4 \mathrm{mbar}$ pressure rise at a depth of $4000 \mathrm{~m}$ will be raised to $20 \mathrm{~cm}$ in water of depth of $5 \mathrm{~m}$; assuming no dissipation of energy. In deepwater, such a wave would initially propagate at a speed of $200 \mathrm{~ms}^{-1}$, and would be ahead of the (weather) pressure wave.. Thus, initially, the two waves would be out of phase, but they may become in-phase when they pass into the shallower water on the shelf.

The weather system that we suggest caused the June 2011 events has many similarities to the Rissaga in Menorca on the 15 June 2006 described above. The atmospheric sounding at Palma shows similarities to the La Coruna ascent for 27 June in the southwest approaches with medium-level instability and negative CAPE, the key to developing downdraughts (Figure $9($ b)). The wind profile of the Menorca event is broadly southwesterly in the middle and upper layers, with quite weak shear $\left(18-25 \mathrm{~ms}^{-1}\right)$. This suggests that convective cells and downdraughts would have maintained their identity as they moved towards the northeast. This conclusion is confirmed by the pressure changes at Palma, and an hour later at Mahon (Monserrat et al., 2006). The modification of the induced sea wave may have been due to a shoaling of the sea floor, or from constructive interference between the sea wave and pressure wave at a set distance parallel to the southeast coast of Mallorca. Another possibility is that there may have been some refraction that focused the wave towards Ciutadella, together with funnelling in the bay and estuary. This may also have set up a sieche in the estuary. These explanations of the Menorca event may also apply to the 'tsunami' wave in the Yealm Estuary. The estuary faces the wave that, with shoaling as it approached the coast, may have resulted in additional resonance as on Menorca and in Japan (as discussed above). Variations in the arrival times of the wave at the different tidal stations may also be accounted for by local bathymetry, the local coastal configuration at the stations and local 'harbour- type' resonances.

\section{Conclusions}

The main source of the 'tsunami' that struck the Yealm Estuary on the 27 June 2011, and the anomalous tide gauge seiche records from the 26 and 27 June, is attributed to thundery cells located in the Bay of Biscay off Brittany with earlier contributions from convective cells located over Portugal and later in the western English Channel (La Manche). Whereas the initial wave created by the weather conditions was small, additional enhancement caused by the Proudman effect resulted in a ten-fold increase in wave height recorded at the gauges. The 'tsunami' wave videoed in the Yealm Estuary, although alleged to be of $0.8 \mathrm{~m}$ height, was probably more like $0.5 \mathrm{~m}$, and is attributed to further resonance as the wave travelled into shallow water, probably due to harbour resonance. The anomalous differences in the timing of the tidal anomalies and tsunami at the different locations are attributed to the formation of several separate waves from different thundery cells as the area of convective activity travelled from Portugal to Brittany and then into the English Channel between 0000 and 1200 UTC. This is the first time that such regional anomalous tidal conditions and particularly a meteotsunami have been positively identified in Spain, Britain and France. Other alternative sources of the 27 June 2011 tsunami and tidal anomalies, such as an earthquake or a tsunami, are discounted.

In the context of global warming, rising sea levels and the possibility of more severe storms, it is relevant to consider how we might better record, model and predict meteotsunamis. UK tide-gauge data has the capability to record sea level at higher frequency (similar to our nearest European neighbours) so we could better record these events. The UK has highly-developed operational storm surge/tide forecast models, and coupling these (at appropriate coastal resolution) to high-resolution $(1.5 \mathrm{~km}) \rightleftharpoons \mathrm{\equiv}$ er forecast models should enable us 4 naterstand better the key physical processes; we now need to explore how this might be carried out.

\section{Acknowledgements}

DRT gratefully acknowledges the assistance during the initial research into this event of Nick Lott and Ben Freeson, both at Magic Seaweed, and Ronan Creach at SHOM. Guy Westbrook at Irish Tides provided tide data for Ballycotton. Thanks to Paul Davies for encouragement and support from the Natural Hazard Partnership, and also thanks for the support of Dave Smith and Will Lang 
from the Met Office. Thanks to Denis Paradis of Meteo France, and Christine Duffy of the Met Office, for provision of high resolution observational data. Thanks to Simon Fitch for permission to use the video screen grab for Figure 8. The paper benefited from comments from two anonymous reviewers. DRT and DL puld with the approval of the Chief Execul of the British Geological Survey, NERC,

\section{References}

Churchill DD, Houston SH, Bond NA.

1995. The Daytona Beach wave of 3-4 July 1992: a shallow-water gravity wave forced by a propagating squall line. Bull. Am. Met. Soc. 76: 21-32.

Dawson AG, Musson RMW, Foster IDL, Brunsden D. 2000. Abnormal historic sea-surface fluctuations, SW England. Mar. Geol. 170(1-2): 59-68.

Haslett SK, Bryant EA. 2009.

Meteorological tsunamis in southern
Britain: an historical review. Geog. Rev. 99: 146-163.

Haslett SK, Mellor HE, Bryant EA. 2009.

Meteo-tsunami hazard associated with summer thunderstorms in the United Kingdom. Phys. Chem. Earth Parts A/B/C 34 17-18, 1016-1022.

Hibiya T, Kajiura K. 1982. Origin of 'Abiki' phenomenon (kind of seiches) in Nagasaki Bay. J. Oceanogr. Soc. Jpn. 38: 172-182.

Jansa A, Monserrat S, Gomis D. 2007

The rissaga of 15 June 2006 in Ciutadella (Menorca), a meteorological tsunami. Adv. Geosci. 12: 1-4.

Monserrat S, Vilibić I, Rabinovich AB. 2006. Meteotsunamis: atmospherically induced destructive ocean waves in the tsunami frequency band. Nat. Hazards Earth Syst. Sci. 6: 1072 OS1.

Newig J, Kelletat $\mathrm{D}$. The North Sea Tsunami of June 5, 1858. J. Coastal Res. 931-941.

Nudelman I, Smith RK, Reeder MJ. 2010. A climatology of pressure jumps around the Gulf of Carpentaria. Aust. Meteorol. Oceanogr. J. 60: 91-101.
Proudman J. 1929. The effects on the sea of changes in atmospheric pressure. Geophys. Suppl. Mon. Notices R. Astr. Soc. 2: 197-209.

Rabinovich AB. 1993. Long Ocean Gravity Waves: Trapping, Resonance, and Leaking (in Russian). Gidrometeoizdat: St. Petersburg, Russia.

Raichlen F. 1966. Harbor resonance, in Estuary and Coastline Hydrodynamics. Ippen AT (ed.). McGraw Hill Book Company: New York, pp 281-340. Vilibic I, Sepic J. 2009. Destructive meteotsunamis along the eastern Adriatic coast: overview. Phys. Chem. Earth Parts A/B/C 34(17-18): 904-917.

\section{Correspondence to: David Tappin drta@bgs.ac.uk}

c) 2013 Royal Meteorological Society and British Crown copyright, the Met Office DOI: 10.1002/wea.2061 
IMPORTANT NOTE: Please mark your corrections and answers to these queries directly onto the proof at the relevant place. Do NOT mark your corrections on this query sheet.

\section{Queries from the Copyeditor:}

AQ1 Please confirm to which of the authors Crown copyright applies (usually this would apply to government employees. If this applies to authors other than those at the Met Office then the Production Editor will need to amend the footnote accordingly.

AQ2 Please provide the volume number for Reference Newig and Kelletat, 2011.

AQ3 Please provide the signifiance of '?' in Table 1. 
Required software to e-Annotate PDFs: Adobe Acrobat Professional or Adobe Reader (version 7.0 or above). (Note that this document uses screenshots from Adobe Reader $\mathrm{X}$ )

The latest version of Acrobat Reader can be downloaded for free at: http://get.adobe.com/uk/reader/

Once you have Acrobat Reader open on your computer, click on the Comment tab at the right of the toolbar:

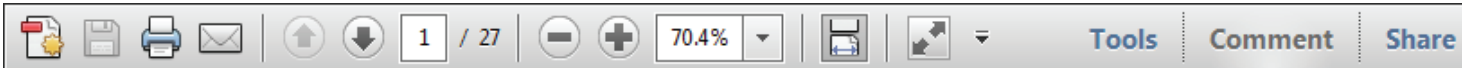

This will open up a panel down the right side of the document. The majority of tools you will use for annotating your proof will be in the Annotations section, pictured opposite. We've picked out some of these tools below:

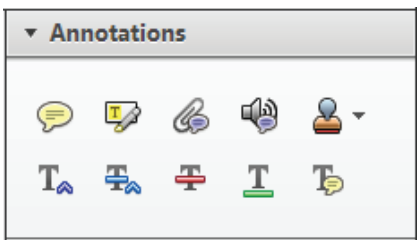

1. Replace (Ins) Tool - for replacing text.

Strikes a line through text and opens up a text box where replacement text can be entered.

\section{How to use it}

- Highlight a word or sentence.

- Click on the Replace (Ins) icon in the Annotations section.

- Type the replacement text into the blue box that appears.

Idard framework for the analysis of $\mathrm{m}$ icy Nevertheless, it alsoled to exog،

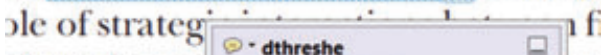
aber of comp 08/06/2011 15:58:17 o is that the $\mathbf{s 1}$, which led of nain compo: be level, are exe nc important wom on लme on virir M henceforth) ${ }^{1}$ we senen the 'hlact 1

3. Add note to text Tool - for highlighting a section to be changed to bold or italic.

T) Highlights text in yellow and opens up a text box where comments can be entered.

How to use it

- Highlight the relevant section of text.

- Click on the Add note to text icon in the Annotations section.

- Type instruction on what should be changed regarding the text into the yellow box that appears.

namic responses of mark ups ent with the VAR evidence

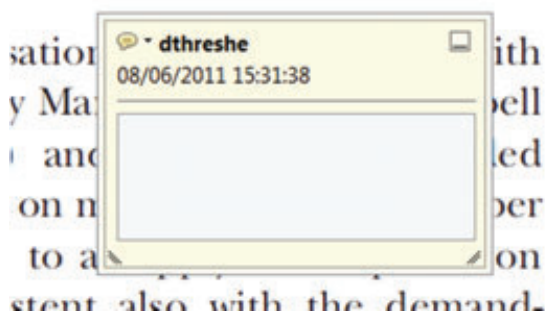

2. Strikethrough (Del) Tool - for deleting text.

雳 Strikes a red line through text that is to be deleted.

\section{How to use it}

- Highlight a word or sentence.

- Click on the Strikethrough (Del) icon in the Annotations section.

there is no room for extra prohts al : ups are zero and the number of cet) values are not determined by Blanchard and Kiyotaki (1987), rfect competition in general equilil ts of aggregate demand and supply lassical framework assuming mono] sen an evorensue number of firme

4. Add sticky note Tool - for making notes at specific points in the text.

Marks a point in the proof where a comment needs to be highlighted.

How to use it

- Click on the Add sticky note icon in the Annotations section.

- Click at the point in the proof where the comment should be inserted.

- Type the comment into the yellow box that appears.

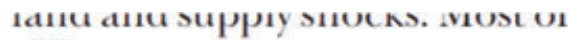

a Pimil
numbe
dard fr:
cy. Nev
le of st
Iber of tomreshe

is that the structure of the sects 
5. Attach File Tool - for inserting large amounts of text or replacement figures.

Inserts an icon linking to the attached file in the appropriate pace in the text.

\section{How to use it}

- Click on the Attach File icon in the Annotations section.

- Click on the proof to where you'd like the attached file to be linked.

- Select the file to be attached from your computer or network.

- Select the colour and type of icon that will appear in the proof. Click OK.

\section{END}

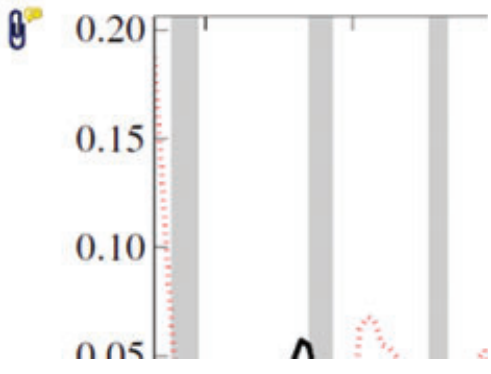

6. Add stamp Tool - for approving a proof if no corrections are required.

$\Omega$ - Inserts a selected stamp onto an appropriate place in the proof.

How to use it

- Click on the Add stamp icon in the Annotations section.

- Select the stamp you want to use. (The Approved stamp is usually available directly in the menu that appears).

- Click on the proof where you'd like the stamp to appear. (Where a proof is to be approved as it is, this would normally be on the first page).

Ir the Dusiness cycie, starung with the on perfect competition, constant ret he otaki (1987), has introduced produc general equilibrium models with nomin

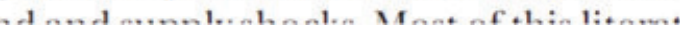

\section{Drawing Markups}

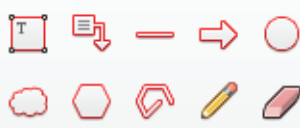

\section{How to use it}

- Click on one of the shapes in the Drawing Markups section.

- Click on the proof at the relevant point and draw the selected shape with the cursor

- To add a comment to the drawn shape, move the cursor over the shape until an arrowhead appears.

- Double click on the shape and type any text in the red box that appears.
7. Drawing Markups Tools - for drawing shapes, lines and freeform annotations on proofs and commenting on these marks.

Allows shapes, lines and freeform annotations to be drawn on proofs and for comment to be made on these marks.

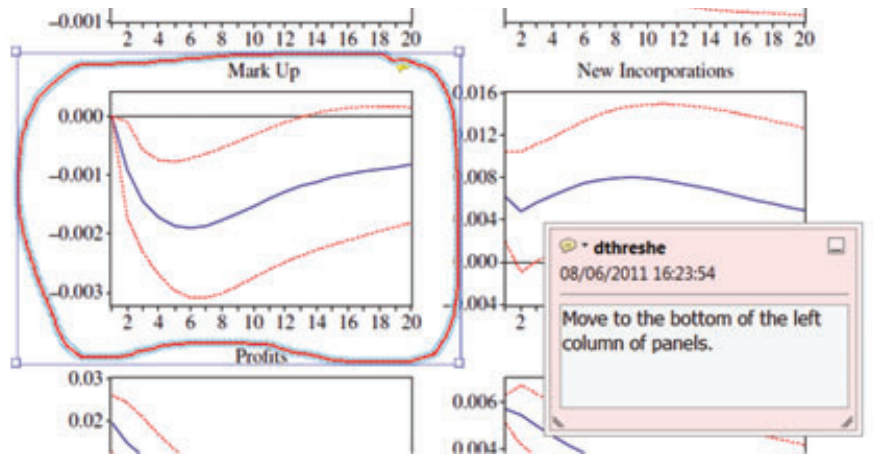

For further information on how to annotate proofs, click on the Help menu to reveal a list of further options:

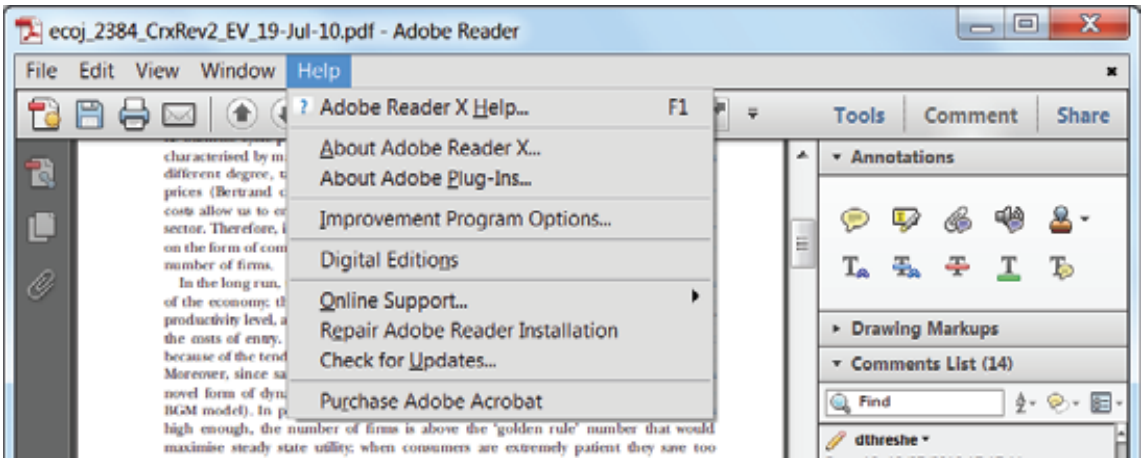

